\title{
Pengaruh Modifikasi AC Chiller Yang Menggunakan Heat Recovery Terhadap Perbandingan Coefficient of Performance (COP)
}

\author{
I Wayan Sutarsa ${ }^{1}$, A.A. Krisna Wira Putra, I Wayan Widiantara \\ ${ }^{1}$ Jurusan Teknik Mesin - Politeknik Negeri Bali, e-mail : wayansutarsa@pnb.ac.id \\ Submisi : 19 Agustus 2019; Penerimaan : 11 Februari 2020
}

\begin{abstract}
ABSTRAK
AC chiller merupakan salah satu jenis sistem tata udara dengan pendinginan tidak langsung karena sistem pendinginannya tidak mendinginkan udara secara langsung tetapi melalui media air, yang terlebih dahulu didinginkan oleh sitem refrigerasi. Air yang telah dingin disirkulasikan ke ruangan dengan pompa ke FCU (Fan Coil Unit) atau AHU (Air Handling Unit). Di dalam sistem refrigerasi, dilakukan modifikasi dengan penambahan komponen Heat recovery, yang dipasang untuk percepat pelepasan panas refrigerant di saluran keluaran Kompresor dan sebelum masuk kondensor pada sistem AC chiller. Penelitian ini membandingkan performansi $A C$ chiller dengan heat recovery dan yang tidak. Pengujian dilakukan sebanyak satu kali pengambilan data. pertama dilakukan pada sistem AC chiller sebelum penambahan komponen heat recovery, yang kedua dilakukan pada sistem AC chiller sesudah penambahan heat recovery. Kedua pengujian ini bertujuan untuk mengetahui perbandingan nilai performansi kerja atau Coefficient Of Performance (COP). Pengujian dilakukan dengan cara pengambilan data secara langsung di sistem terhadap tekanan refrigerant, temperature dan daya listrik.

Hasil modifikasi menunjukkan sistem dapat berjalan dengan baik dan hasil pengujian menunjukkan performansi sistem dengan heat recovery hasilnya lebih baik sampai 8, sedangkan yang tidak hanya sampai 6,4. dapat disimpulkan bahwa AC chiller yang ditambahkan dengan komponen heat recovery dapat meningkatkan kinerja dari sistem tersebut
\end{abstract}

Kata kunci : AC chiller; heat recovery; coefficient of performance (COP).

\section{PENDAHULUAN}

\section{Latar Belakang}

AC chiller merupakan salah satu alat pengkondisian udara selain $A C$ Split, yang banyak dipasang di Perkantoran, Hotel dan jenis bangunan yang mempunyai beban pendinginan yang besar, jenis $A C$ chiller dipilih karena tidak berisik, pemeliharaan dan oprasionalnya lebih mudah. AC Chiller atau mesin refrigerasi adalah peralatan yang bisa menghasilkan air dingin (chilled water) dan membuang kalor ke udara (atmosfir) melalui menara pendingin (cooling tower). Air dingin yang dihasilkan selanjutnya didistribusikan ke FCU (Fan Coil Unit) atau AHU (Air Handling Unit). Pada sistem ini letak ruang $A H U / F C U$, mesin chiller dan cooling tower terpisah dengan ruangan yang dikondisikan udaranya [1]. AC chiller Unit ini merupakan mesin pengkondisian udara yang digunakan sebagai alat praktikum di Laboratorium Tata Udara Terapan, Jurusan teknik Mesin, Politeknik Negeri Bali. yang menggunakan siklus kompresi uap dan R22 sebagai fluida kerjanya (refrigerant), yang komponen utamanya yaitu kompresor, kondensor, katup ekspansi dan evaporator. Dalam 
proses pelepasan panas refrigerant di kondesor sangatlah penting dalam proses sistem tata udara, jika hal ini tidak berlangsung optimal pengkondisian ruangan menjadi terganggu. Dengan permasalahan tersebut kami membuat karya tulis membahas penambahan heat recovery Tujuan Penelitian

Adapun tujuan yang ingin dicapai pada penelitian ini adalah untuk mengetahui kinerja (COP) AC chiller Unit dengan menggunakan heat recovery dan yang tidak.

Adapun manfaat penelitian ini adalah :

1. Untuk mengembangkan alat-alat praktek yang ada di Laboratorium Jurusan Teknik Mesin, Politeknik Negeri Bali khususnya alat praktek mata kuliah Tata Udara Terapan.

2. Mahasiswa mengetahui cara kerja dan menganalisa $A C$ chiller Unit dengan menggunakan heat recovery dan yang tidak.

\section{METODE PENELITIAN}

\section{Bahan Penelitian}

Bahan penelitian yang digunakan dalam penelitian ini adalah $A C$ chiller Unit dengan kapasitas $5 \mathrm{PK}$, sedangkan refrigerant yang digunakan adalah $\mathrm{R} 22$. Adapun sistem pengistalasian $A C$ chiller Unit seperti pada gambar 2.

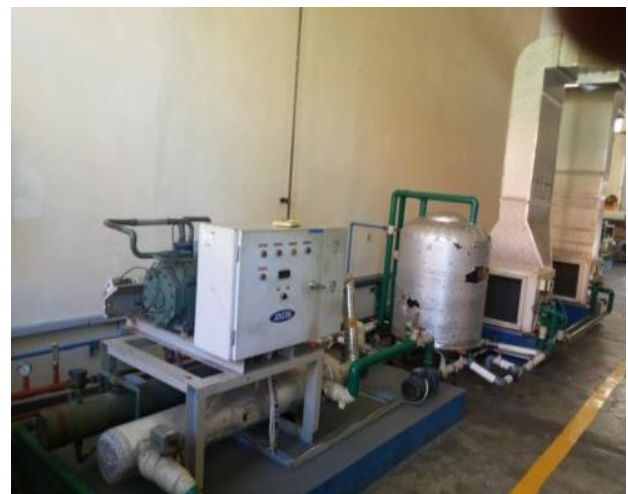

Gambar 1. AC chiller Unit di dalam $A C$ chiller Unit yang ada di Laboratorium Tata Udara, Jurusan Teknik Mesin, Politeknik Negeri Bali sehingga mahasiswa lebih mudah memahami sistem pengkondisian udara dalam ruangan yang menggunakan $A C$ chiller Unit.

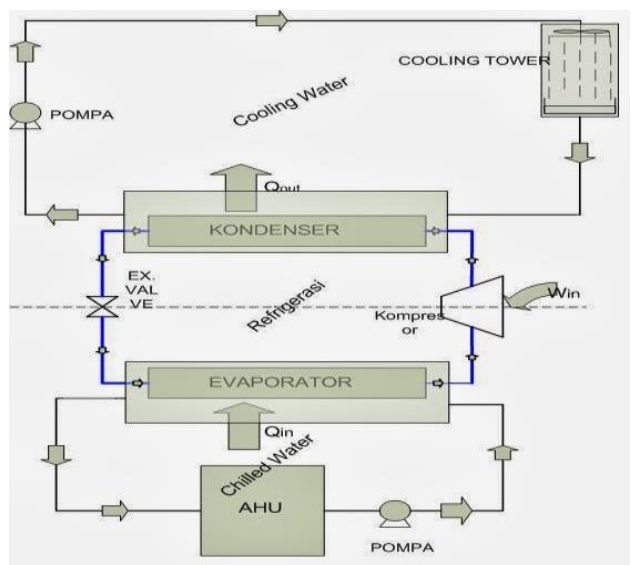

Gambar 2. Instalasi AC chiller Unit.

Dalam sistem AC chiller Unit pemasangan heat recovery diletakan pada sisi keluar kompresor atau sebelum masuk kondensor, yang digunakan untuk mempercepat proses pelepasan kalor refrigerant [3]. Alat ini juga bisa digunakan sebagai energi memanaskan air yang akan dimanfaatkan sebagai kebutuhan industry, rumah makan ataupun yang lainya. Gambar heat recovery seperti di gambar 3, dan pemasangan pada sistem seperti di gambar 4 .

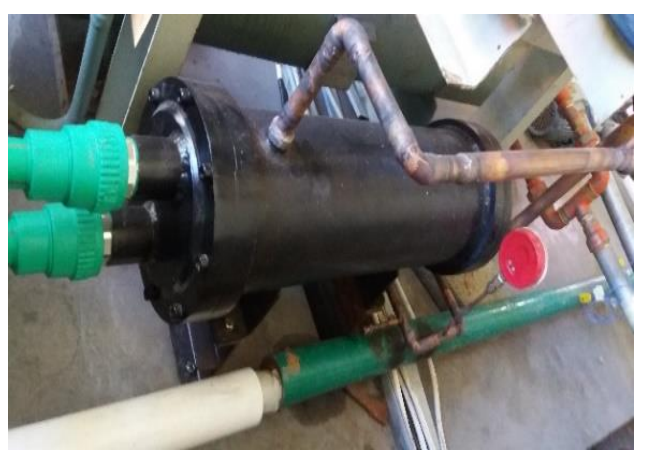

Gambar 3. Heat Recovery 


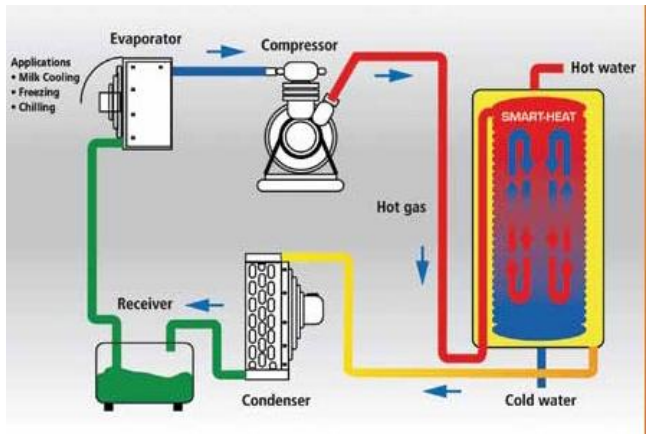

Gambar 4. Sistem Heat Recovery [3]

Alat dan bahan yang digunakan untuk pengambilan data pengujian adalah : Thermocouple, Tang Ampere, Power analyzer, Ultrasonic Flowmeter, Stopwatch, Charging Manifol.

\section{Cara Kerja}

Dalam menentukan analisa hasil pengujian diperlukan beberapa persamaan. Perhitungan yang digunakan didalam menentukan COP AC Trainer Unit ini adalah sebagai berikut :

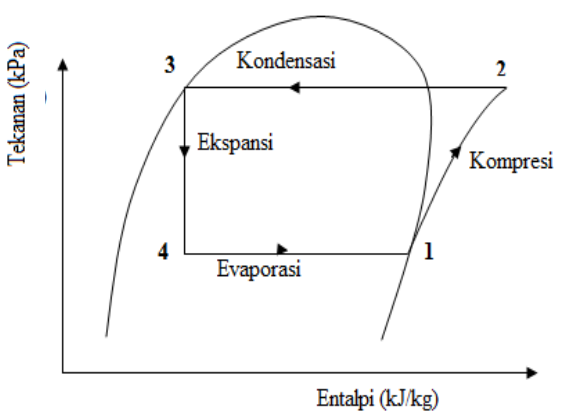

Gambar 5. P-h Diagram Siklus Kompresi Uap

Efek Refrigerasi (ER) ; merupakan jumlah kalor yang diserap oleh refrigeran di dalam evavorator untuk setiap satu satuan massa refrigeran, terjadi pada proses 4 ke 1 seperti pada gambar 5 , persamaannya adalah:

$E R=h 1-h 4(\mathrm{~kJ} / \mathrm{kg})$

Kerja Kompresi $\left(w_{k}\right)$; proses kerja yang dibutuhkan pada proses kompresi refrigeran di dalam kompresor, besarnya sama dengan selisih entalpi pada proses 1 ke 2, persamaannya adalah : $w k=h 2-h 1(\mathrm{~kJ} / \mathrm{kg})$

Daya Aktual Kompresor (Pk) ; Daya aktual dibutuhkan oleh kompresor untuk melakukan kerja kompresi persamaannya adalah :

$P$ aktual $=$ V.I. $\operatorname{Cos} \theta$

Kalor yang dibuang di Kondensor (qk) ; Kalor yang dibuang oleh refrigeran di kondensor sama dengan kalor yang diserap oleh refrigeran di evaporator ditambah dengan kalor yang setara dengan kerja kompresi di kompresor. Secara sistematis, qk dinyatakan sebagai berikut :

$q k=h 2-h 3 \quad(\mathrm{~kJ} / \mathrm{kg})$

dimana : $\mathrm{h}_{2} \& \mathrm{~h}_{3}=$ entalphi refrigeran pada sisi isap dan keluar kondensor $(\mathrm{kJ} / \mathrm{kg})$

Coefficient of Performance (COP) ; perbandingan antara efek refrigerasi (ER) sistem dengan kerja kompresi (wk), persamaannya adalah :

$C O P=E R / w k=Q E v a p / w k$

Menghitung Qevap

Qevap $=$ Qwater

Qwater $=\dot{\mathrm{m}} \mathrm{chw}$. Cpwater..$(T c h w E-T c h w L)(6)$

Menghitung m $\mathrm{chw}$ (chille water)

$\dot{\mathrm{m}} \mathrm{ch} w=\rho$ water. Vchw

Keterangan :

COP coefficient of performance

chw chill water

$h \quad$ specific enthalpy $(\mathrm{KJ} / \mathrm{Kg})$

$\dot{m} \quad$ mass flow rate $(\mathrm{kg} / \mathrm{s})$

$P \quad$ pressure (Psi)

$Q \quad$ heat capacity $(K J)$

$T$ temperature $\left({ }^{\circ} \mathrm{C}\right)$

$V \quad$ Volume $\left(\mathrm{m}^{3} / \mathrm{s}\right)$

Dalam penelitian ini. Pengambilan data pertama dilakukan pada sistem $A C$ chiller sebelum penambahan komponen heat recovery. dan yang kedua dilakukan pada sistem $A C$ chiller 
sesudah penambahan heat recovery, dan data yang di ambil langsung pada perangkat $A C$ chiller, Data diambil dengan cara mengukur dan mencatat langsung variabel-variabel yang diperlukan yang meliputi : Temperatur $(\mathrm{T})$, Tekanan $(\mathrm{P})$, Arus (I), Tegangan
(V), Aliran Air (L). Data diambil setelah sistem bekerja secara normal, maka akan langsung dilakukan pengambilan data yang dilakukan selama 1 jam. Pengambilan data dilakukan setiap 5 menit. Pengukuran temperatur terletak pada titik gambar berikut :

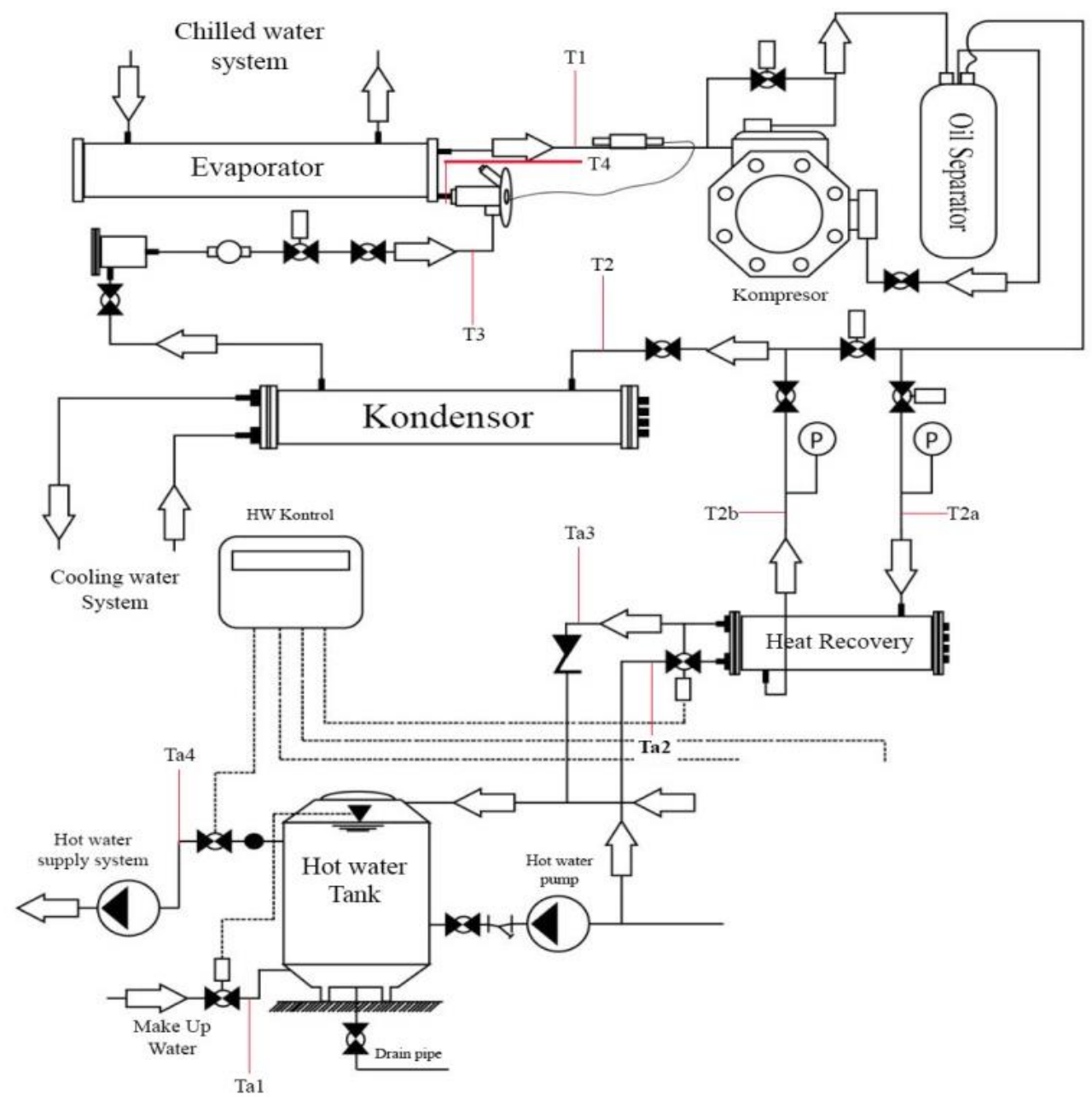

Keterangan :

Gambar 6. Titik pengukuran temperatur pada sistem

- T1 merupakan temperatur refrigeran pada sisi masuk kompresor

- T2 merupakan temperatur refrigeran pada sisi masuk kondensor

- T3 merupakan temperatur refrigeran pada sisi masuk katup ekspansi

- T4 merupakan temperatur refrigeran pada sisi masuk evaporator

- T2a merupakan temperatur refrigeran pada sisi masuk heat recovery

- T2b merupakan temperatur refrigeran pada sisi keluar heat recovery

- Ta1 merupakan temperatur air yang akan digunakan untuk suplai air panas

- Ta2 merupakan temperatur air yang masuk ke heat recovery

- Ta3 merupakan temperatur air yang keluar dari heat recovery

- Ta4 merupakan temperatur air yang akan disirkulasikan untuk suplai pengguna 


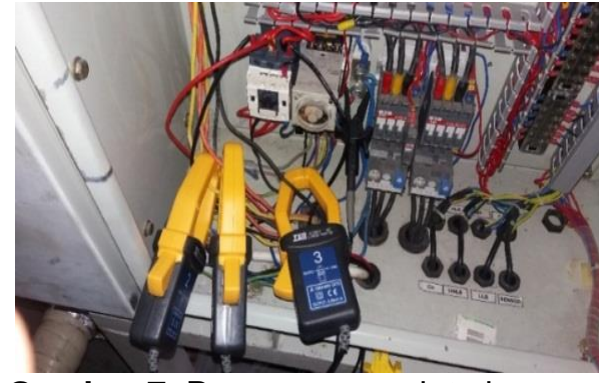

Gambar 7. Pemasangan alat ukur arus listrik

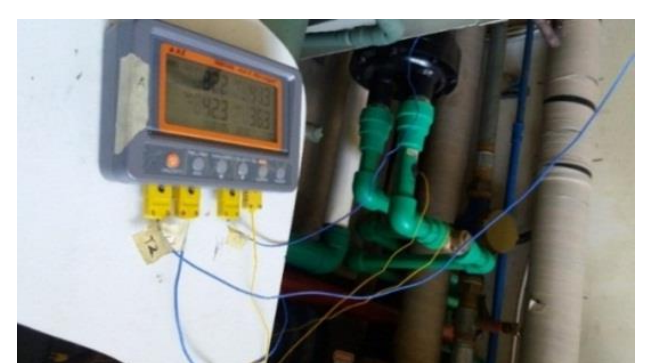

Gambar 8. Proses pengukuran temperatur

\section{HASIL DAN PEMBAHASAN}

Hasil

Pengukuran dilakukan pada sistem $A C$ chiller sebelum penambahan komponen heat recovery, pengukuran selanjutnya dilakukan pada sistem $A C$ chiller yang sudah ditambahkan dengan komponen heat recovery untuk mengetahui performansi dari kinerja sistem AC chiller. Dari pengujian didapatkan data hasil pengukuran, selanjutnya digunakan untuk menghitung beberapa besaran yang diperlukan dalam proses analisa. Adapun hasilnya di tabel 1.

Tabel 1. Data Hasil Pengujian AC chiller tanpa komponen heat recovery

\begin{tabular}{|c|c|c|c|c|c|c|c|c|c|c|c|c|c|c|}
\hline \multirow{3}{*}{ wkt } & \multirow{3}{*}{$\mathbf{P}_{\text {high }}$} & \multirow{3}{*}{$\mathbf{P}_{\text {Low }}$} & \multirow{3}{*}{$\mathbf{P}$} & \multicolumn{4}{|c|}{ Evaporator } & \multicolumn{4}{|c|}{ Kondensor } & \multirow{2}{*}{\multicolumn{2}{|c|}{$\begin{array}{c}\begin{array}{c}\text { Cooling } \\
\text { tower }\end{array} \\
\text { Air }\end{array}$}} & \multirow{3}{*}{$T_{\text {Ling }}$} \\
\hline & & & & \multicolumn{2}{|c|}{ Refigeran } & \multicolumn{2}{|c|}{ Air } & \multicolumn{2}{|c|}{ Refigeran } & \multicolumn{2}{|c|}{ Air } & & & \\
\hline & & & & $T_{\text {in }}$ & $T_{\text {out }}$ & $T_{\text {in }}$ & $\mathbf{T}_{\text {out }}$ & $T_{\text {in }}$ & $T_{\text {out }}$ & $T_{\text {in }}$ & $T_{\text {out }}$ & $T_{\text {in }}$ & $T_{\text {out }}$ & \\
\hline mnt & Psi & Psi & Kw & ${ }^{\circ} \mathrm{C}$ & ${ }^{\circ} \mathrm{C}$ & ${ }^{\circ} \mathrm{C}$ & ${ }^{\circ} \mathrm{C}$ & ${ }^{\circ} \mathrm{C}$ & ${ }^{\circ} \mathrm{C}$ & ${ }^{\circ} \mathrm{C}$ & ${ }^{\circ} \mathrm{C}$ & ${ }^{\circ} \mathrm{C}$ & ${ }^{\circ} \mathrm{C}$ & ${ }^{\circ} \mathrm{C}$ \\
\hline 5 & 240 & 54 & 53 & 9 & $\begin{array}{c}15 . \\
7\end{array}$ & $\begin{array}{c}15 . \\
7\end{array}$ & 7.7 & $\begin{array}{c}82 . \\
1\end{array}$ & 42.1 & $\begin{array}{c}29 . \\
4\end{array}$ & 32.9 & $\begin{array}{c}34 . \\
1\end{array}$ & 28.9 & 29 \\
\hline 10 & 240 & 54 & 52 & 9 & $\begin{array}{c}15 . \\
8\end{array}$ & $\begin{array}{c}15 . \\
8\end{array}$ & 7.6 & $\begin{array}{c}82 . \\
6\end{array}$ & 42.2 & $\begin{array}{c}29 . \\
2\end{array}$ & 32.9 & $\begin{array}{c}33 . \\
4\end{array}$ & 29.8 & 29.3 \\
\hline 15 & 240 & 54 & 52 & 8.8 & $\begin{array}{c}16 . \\
3\end{array}$ & $\begin{array}{c}15 . \\
7\end{array}$ & 7.6 & 83 & 42.4 & $\begin{array}{c}29 . \\
4\end{array}$ & 32.7 & $\begin{array}{c}34 . \\
1\end{array}$ & 28.8 & 29.3 \\
\hline 20 & 240 & 54 & 53 & 8.9 & $\begin{array}{c}16 . \\
3\end{array}$ & $\begin{array}{c}15 . \\
9\end{array}$ & 7.6 & $\begin{array}{c}82 . \\
8\end{array}$ & 41.7 & $\begin{array}{c}29 . \\
1\end{array}$ & 32.8 & $\begin{array}{c}33 . \\
3\end{array}$ & 29.6 & 29.1 \\
\hline 25 & 240 & 54 & 53 & 8.8 & $\begin{array}{c}16 . \\
5\end{array}$ & $\begin{array}{c}15 . \\
6\end{array}$ & 7.6 & $\begin{array}{c}82 . \\
7\end{array}$ & 42.1 & $\begin{array}{c}29 . \\
3\end{array}$ & 32.9 & $\begin{array}{c}33 . \\
8\end{array}$ & 28.8 & 29.2 \\
\hline 30 & 240 & 54 & 53 & 8.7 & $\begin{array}{c}16 . \\
7\end{array}$ & $\begin{array}{c}15 . \\
5\end{array}$ & 7.5 & $\begin{array}{c}82 . \\
6\end{array}$ & 42.7 & 29 & 32.5 & $\begin{array}{c}33 . \\
2\end{array}$ & 29.4 & 29.2 \\
\hline 35 & 240 & 54 & 53 & 8.7 & $\begin{array}{c}16 . \\
7\end{array}$ & $\begin{array}{c}15 . \\
5\end{array}$ & 7.5 & $\begin{array}{c}82 . \\
8\end{array}$ & 42.7 & $\begin{array}{c}29 . \\
4\end{array}$ & 32.7 & $\begin{array}{c}33 . \\
8\end{array}$ & 28.8 & 29 \\
\hline 40 & 240 & 54 & 53 & 8.7 & $\begin{array}{c}16 . \\
7\end{array}$ & $\begin{array}{c}15 . \\
4\end{array}$ & 7.4 & $\begin{array}{c}82 . \\
7\end{array}$ & 42.2 & $\begin{array}{c}28 . \\
8\end{array}$ & 32.1 & $\begin{array}{c}33 . \\
3\end{array}$ & 29.3 & 29.3 \\
\hline 45 & 240 & 54 & 53 & 8.4 & $\begin{array}{c}16 . \\
6\end{array}$ & $\begin{array}{c}15 . \\
3\end{array}$ & 7.3 & $\begin{array}{c}81 . \\
7\end{array}$ & 42 & $\begin{array}{c}28 . \\
9\end{array}$ & 32.7 & $\begin{array}{c}33 . \\
2\end{array}$ & 28.7 & 28.5 \\
\hline 50 & 240 & 54 & 53 & 8.6 & $\begin{array}{c}16 . \\
7\end{array}$ & $\begin{array}{c}15 . \\
4\end{array}$ & 7.4 & $\begin{array}{c}82 . \\
2\end{array}$ & 42.4 & $\begin{array}{c}29 . \\
9\end{array}$ & 32.7 & $\begin{array}{c}33 . \\
1\end{array}$ & 29.3 & 28.9 \\
\hline 55 & 240 & 54 & 53 & 8.6 & $\begin{array}{c}16 . \\
5\end{array}$ & $\begin{array}{c}15 . \\
4\end{array}$ & 7.4 & $\begin{array}{c}82 . \\
8\end{array}$ & 42.6 & $\begin{array}{c}29 . \\
2\end{array}$ & 32.9 & $\begin{array}{c}33 . \\
2\end{array}$ & 29.7 & 28.9 \\
\hline 60 & 240 & 54 & 53 & 8.8 & $\begin{array}{c}16 . \\
3\end{array}$ & $\begin{array}{c}15 . \\
5\end{array}$ & 7.5 & $\begin{array}{c}82 . \\
8\end{array}$ & 42.6 & $\begin{array}{c}29 . \\
2\end{array}$ & 32.7 & $\begin{array}{c}33 . \\
1\end{array}$ & 29.5 & 28.6 \\
\hline
\end{tabular}


Tabel 2. Data Hasil Pengujian AC chiller menggunakan komponen heat recovery

\begin{tabular}{|c|c|c|c|c|c|c|c|c|c|c|c|c|c|c|}
\hline \multirow{3}{*}{ wkt } & \multirow{3}{*}{$\mathbf{P}_{\text {high }}$} & \multirow{3}{*}{$\mathbf{P}_{\text {Low }}$} & \multirow{3}{*}{$\mathbf{P}$} & \multicolumn{4}{|c|}{ Evaporator } & \multicolumn{4}{|c|}{ Kondensor } & \multirow{2}{*}{\multicolumn{2}{|c|}{$\begin{array}{c}\begin{array}{c}\text { Cooling } \\
\text { tower }\end{array} \\
\text { Air }\end{array}$}} & \multirow{3}{*}{$T_{\text {Lingk }}$} \\
\hline & & & & \multicolumn{2}{|c|}{ Refigeran } & \multicolumn{2}{|c|}{ Air } & \multicolumn{2}{|c|}{ Refigeran } & \multicolumn{2}{|c|}{ Air } & & & \\
\hline & & & & $T_{\text {in }}$ & $T_{\text {out }}$ & $\mathbf{T}_{\text {in }}$ & $\mathrm{T}_{\text {out }}$ & $T_{\text {in }}$ & $T_{\text {out }}$ & $T_{\text {in }}$ & $T_{\text {out }}$ & $\mathbf{T}_{\text {in }}$ & $T_{\text {out }}$ & \\
\hline mnt & Psi & Psi & Kw & ${ }^{\circ} \mathrm{C}$ & ${ }^{\circ} \mathrm{C}$ & ${ }^{\circ} \mathrm{C}$ & ${ }^{\circ} \mathrm{C}$ & ${ }^{\circ} \mathrm{C}$ & ${ }^{\circ} \mathrm{C}$ & ${ }^{\circ} \mathrm{C}$ & ${ }^{\circ} \mathrm{C}$ & ${ }^{\circ} \mathrm{C}$ & ${ }^{\circ} \mathrm{C}$ & ${ }^{\circ} \mathrm{C}$ \\
\hline 5 & 230 & 50 & 5.8 & 6.3 & $\begin{array}{c}12 . \\
7\end{array}$ & $\begin{array}{c}18 . \\
8\end{array}$ & 9.9 & $\begin{array}{c}86 . \\
6\end{array}$ & $\begin{array}{c}39 . \\
4\end{array}$ & $\begin{array}{c}24 . \\
3\end{array}$ & 33.2 & $\begin{array}{c}32 . \\
6\end{array}$ & $\begin{array}{c}28 . \\
5\end{array}$ & 40.6 \\
\hline 10 & 230 & 50 & 5.8 & 6.7 & $\begin{array}{c}12 . \\
6\end{array}$ & $\begin{array}{c}18 . \\
3\end{array}$ & 9.6 & $\begin{array}{c}86 . \\
1\end{array}$ & $\begin{array}{c}41 . \\
4\end{array}$ & $\begin{array}{c}23 . \\
4\end{array}$ & 33.1 & $\begin{array}{c}32 . \\
6\end{array}$ & $\begin{array}{c}28 . \\
3\end{array}$ & 38.6 \\
\hline 15 & 230 & 50 & 5.7 & 6.7 & $\begin{array}{c}12 . \\
1\end{array}$ & $\begin{array}{c}17 . \\
6\end{array}$ & 9.5 & $\begin{array}{c}86 . \\
6\end{array}$ & $\begin{array}{c}43 . \\
3\end{array}$ & $\begin{array}{c}23 . \\
8\end{array}$ & 32.9 & $\begin{array}{c}32 . \\
8\end{array}$ & $\begin{array}{c}28 . \\
4\end{array}$ & 37.1 \\
\hline 20 & 230 & 50 & 5.8 & 6.5 & $\begin{array}{c}11 . \\
9\end{array}$ & $\begin{array}{c}17 . \\
4\end{array}$ & 9.4 & $\begin{array}{c}85 . \\
9\end{array}$ & $\begin{array}{c}43 . \\
7\end{array}$ & $\begin{array}{c}24 . \\
5\end{array}$ & 32.2 & $\begin{array}{c}32 . \\
6\end{array}$ & $\begin{array}{c}28 . \\
6\end{array}$ & 36.9 \\
\hline 25 & 230 & 50 & 5.8 & 7.1 & $\begin{array}{c}11 . \\
9\end{array}$ & $\begin{array}{c}17 . \\
3\end{array}$ & 9.4 & $\begin{array}{c}85 . \\
7\end{array}$ & 43 & $\begin{array}{c}23 . \\
8\end{array}$ & 32.6 & $\begin{array}{c}32 . \\
8\end{array}$ & $\begin{array}{c}28 . \\
4\end{array}$ & 36.7 \\
\hline 30 & 230 & 50 & 5.8 & 5.7 & 12 & $\begin{array}{c}17 . \\
2\end{array}$ & 9.4 & $\begin{array}{c}85 . \\
7\end{array}$ & $\begin{array}{c}39 . \\
4\end{array}$ & $\begin{array}{c}22 . \\
9\end{array}$ & 33.2 & $\begin{array}{c}32 . \\
8\end{array}$ & $\begin{array}{c}28 . \\
6\end{array}$ & 39.8 \\
\hline 35 & 230 & 50 & 5.8 & 6.3 & $\begin{array}{c}12 . \\
1\end{array}$ & $\begin{array}{c}17 . \\
2\end{array}$ & 9.5 & $\begin{array}{c}85 . \\
5\end{array}$ & $\begin{array}{c}42 . \\
4\end{array}$ & $\begin{array}{c}22 . \\
7\end{array}$ & 32.9 & $\begin{array}{c}32 . \\
9\end{array}$ & $\begin{array}{c}28 . \\
6\end{array}$ & 37.9 \\
\hline 40 & 230 & 50 & 5.8 & 6 & $\begin{array}{c}12 . \\
1\end{array}$ & $\begin{array}{c}17 . \\
3\end{array}$ & 9.6 & $\begin{array}{c}85 . \\
9\end{array}$ & $\begin{array}{c}42 . \\
3\end{array}$ & $\begin{array}{c}23 . \\
3\end{array}$ & 32.8 & $\begin{array}{c}32 . \\
8\end{array}$ & $\begin{array}{c}28 . \\
7\end{array}$ & 37.7 \\
\hline 45 & 230 & 50 & 5.8 & 5.3 & $\begin{array}{c}12 . \\
2\end{array}$ & $\begin{array}{c}17 . \\
3\end{array}$ & 9.7 & $\begin{array}{c}86 . \\
4\end{array}$ & $\begin{array}{c}40 . \\
4\end{array}$ & $\begin{array}{c}22 . \\
7\end{array}$ & 32.7 & $\begin{array}{c}32 . \\
9\end{array}$ & $\begin{array}{c}28 . \\
7\end{array}$ & 39.4 \\
\hline 50 & 230 & 50 & 5.8 & 6.3 & $\begin{array}{c}12 . \\
3\end{array}$ & $\begin{array}{c}17 . \\
3\end{array}$ & 9.7 & $\begin{array}{c}86 . \\
4\end{array}$ & $\begin{array}{c}39 . \\
6\end{array}$ & $\begin{array}{c}24 . \\
3\end{array}$ & 33.1 & $\begin{array}{c}32 . \\
8\end{array}$ & $\begin{array}{c}28 . \\
5\end{array}$ & 40 \\
\hline 55 & 230 & 50 & 5.8 & 6.1 & $\begin{array}{c}12 . \\
2\end{array}$ & $\begin{array}{c}17 . \\
3\end{array}$ & 9.7 & $\begin{array}{c}86 . \\
6\end{array}$ & $\begin{array}{c}43 . \\
3\end{array}$ & 24 & 32.6 & $\begin{array}{c}32 . \\
9\end{array}$ & $\begin{array}{c}28 . \\
6\end{array}$ & 36.1 \\
\hline 60 & 230 & 50 & 5.8 & 5.3 & $\begin{array}{c}12 . \\
3\end{array}$ & $\begin{array}{c}17 . \\
3\end{array}$ & 9.7 & $\begin{array}{c}86 . \\
4\end{array}$ & $\begin{array}{c}43 . \\
8\end{array}$ & $\begin{array}{c}23 . \\
6\end{array}$ & 32.7 & $\begin{array}{c}32 . \\
8\end{array}$ & $\begin{array}{c}28 . \\
5\end{array}$ & 35.8 \\
\hline
\end{tabular}

\section{Pembahasan}

Dari hasil pengujian yang telah dilakukan pada tabel 1 dan 2 . Perhitungan COP dilakukan pada kalor yang diserap evaporator (Qevap) dan dari aliran air dingin di sisi evaporator, ini merupakan keseimbangan energy yang ada di evaporator, sehingga dalam perhitungan akan mendapakan nilai COP aktual.

1.Menghitung COP AC chiller tanpa komponen heat recovery

COP $=\frac{\text { Qevap }}{\text { Wcomp }}$

Menghitung Qevap

Qevap $=$ Qwater

Qwater $=\dot{\text { mchw}}$. Cpwater.$($ TchwE - TchwL $)$

Menghitung michw (chille water)

$\dot{\mathrm{m}} c h w=$ owater.$V c h w$
Selama 1 jam pengujian chill water yang digunakan $7 \mathrm{~m}^{3}$ sehingga didapatkan perhitungan berikut :

Vchw $=0.000972 \frac{\mathrm{m}^{3}}{\mathrm{~s}}$

$\dot{\mathrm{m}} \mathrm{chw}=0.972 \mathrm{~kg} / \mathrm{s}$

Menghitung Qevap

Cpwater $=4.179 \mathrm{~kJ} / \mathrm{kg}^{\circ} \mathrm{C}$

Qevap $=\dot{\mathrm{m}}$ chw.Cpwater $\cdot($ TchwE - TchwL $)$

$$
=32.503 \mathrm{~kJ} / \mathrm{s}
$$

Menghitung COP

COP $=\frac{\text { Q evap }}{\text { Pcomp }}=6.1$

Dengan cara perhitungan yang sama dilakukan pada data-data berikutnya, maka nilai COP pada sistem AC chiller tanpa penambahan heat recovery dapat dilihat pada tabel 3 . 
Tabel 3 : Nilai COP AC chiller tanpa komponen heat recovery

\begin{tabular}{|c|c|c|c|c|c|c|c|c|c|c|c|c|}
\hline $\begin{array}{c}\text { Waktu } \\
\text { (mnt) }\end{array}$ & 5 & 10 & 15 & 20 & 25 & 30 & 35 & 40 & 45 & 50 & 55 & 60 \\
\hline COP1 & 6.1 & 6.4 & 6.3 & 6.3 & 6.1 & 6.1 & 6.1 & 6.1 & 6.1 & 6.1 & 6.1 & 6.1 \\
\hline
\end{tabular}

\section{Menghitung COP $A C$ chiller dengan penambahan heat recovery}

$$
\begin{array}{r}
\text { COP }=\frac{\text { Qcooling }+ \text { Qheating }}{\text { Wcomp }} \\
=\frac{\text { Qevap }+ \text { Qheat recovery }}{\text { Wcomp }}
\end{array}
$$

Menghitung Qevap

Qevap $=$ Qwater $=$

$\dot{\mathrm{m}} \mathrm{chw}$. Cpwater. $(T \operatorname{chw} E-T \operatorname{ch} w L)$

Menghitung michw (chille water)

$\dot{\mathrm{m}} \mathrm{ch} w=\rho$ water. Vchw

Selama 1 jam pengujian chill water yang digunakan $8 \mathrm{~m}^{3}$ sehingga didapatkan :

$V$ chw $=0.001 \frac{\mathrm{m}^{3}}{\mathrm{~s}}$

$\dot{\mathrm{m}} \mathrm{ch} w=1.1 \mathrm{~kg} / \mathrm{s}$

Menghitung Qevap :

Cpwater $=4.179 \mathrm{~kJ} / \mathrm{kg}^{\circ} \mathrm{C}$

Qevap $=\dot{\mathrm{m}} \mathrm{chw}$. Cpwater..$($ TchwE - chwL $)$

$$
=41.32563 \mathrm{~kJ} / \mathrm{s}
$$

\section{Menghitung Qheat recovery}

Qheat recovery $=$

mंchw.Cpwater. (TchwE-TchwL)
Menghitung michw (chille water).

$\dot{\mathrm{m}} \mathrm{ch} w=\rho$ water. Vchw

Selama 1 jam pengujian air yang digunakan pada heat recovery sebanyak $42 \ell / m n t$ sehingga didapatkan :

$\dot{\mathrm{m}} \mathrm{ch} w=0.7 \mathrm{~kg} / \mathrm{s}$

Menghitung Qheat recovery

Cpwater $=4.179 \mathrm{~kJ} / \mathrm{kg}^{\circ} \mathrm{C}$

Qevap $=\dot{\mathrm{m}}$ chw.Cpwater.$(T c h w E-T c h w L)$

$$
=6.14313 \mathrm{~kJ} / \mathrm{s}
$$

Menghitung COP

$$
\begin{aligned}
\text { COP }= & \frac{\text { Qcooling }+ \text { Qheating }}{\text { Wcomp }} \\
& =\frac{\text { Qevap }+ \text { Qheat recovery }}{\text { Wcomp }} \\
& =8.1
\end{aligned}
$$

Dengan cara perhitungan yang sama kemudian dilakukan pada data-data berikutnya maka nilai $C O P$ pada sistem $A C$ chiller dengan penambahan komponen heat recovery dapat dilihat pada tabel 4. Dari hasil perhitungan yang diperoleh maka didapatkan grafik pada gambar 8 .

Tabel 4 : Nilai COP AC chiller dengan penambahan heat recovery

\begin{tabular}{|c|c|c|c|c|c|c|c|c|c|c|c|c|}
\hline $\begin{array}{c}\text { Waktu } \\
\text { (mnt) }\end{array}$ & 5 & 10 & 15 & 20 & 25 & 30 & 35 & 40 & 45 & 50 & 55 & 60 \\
\hline COP2 & 8.1 & 8.1 & 7.5 & 6.6 & 7.1 & 6.9 & 7.2 & 7 & 6.6 & 7.1 & 7.2 & 7 \\
\hline
\end{tabular}

Berdasarkan gambar 8 disimpulkan bahwa sistem $A C$ chiller yang ditambahkan dengan komponen heat recovery dapat meningkatkan nilai COP dari sistem sebesar $14,46 \%$. Hal ini disebabkan air yang mengalir melalui heat recovery membantu proses penyerapan kalor pada refrigerant yang baru keluar dari kompresor sehingga refrigerant yang keluar dari heat recovery akan mengalami penurunan temperatur sebelum memasuki kondensor. Pada refrigerant yang keluar dari kondesor juga mengalami penurunan tempertaur dikarenakan adanya media air yang membantu 
proses penyerapan kalor kembali sehingga pada sistem $A C$ chiller dengan penambahan heat recovery akan mengalami dua kali proses penyerapan kalor pada media air yang dapat menurunkan temperatur refrigerant lebih cepat.

Hal-hal yang mempengaruhi naik turunnya nilai $C O P$ pada sistem $A C$ chiller dengan penambahan komponen heat recovery yang pertama dikarenakan faktor tekanan refrigerant. Penambahan komponen heat recovery pada AC chiller tentunya akan menambah ruang yang harus diisi refrigerant dengan demikian penambahan refrigerant pada sistem harus disesuaikan kembali agar sistem dapat bekerja dengan optimal. Kedua dipengaruhi dari selisih temperatur air yang masuk dan keluar $(\Delta T)$ dari heat recovery dimana semakin besar nilai $\Delta$ Tair maka semakin besar pula nilai COP yang akan didapatkan pada sistem begitu pula sebaliknya semakin kecil nilai $\Delta$ Tair pada heat recovery maka semakin kecil pula nilai COP yang akan didapat pada sistem. Ketiga dipengaruhi dari temperatur lingkungan. Temperatur lingkungan yang tinggi akan menghambat perpindahan panas yang dilepaskan cooling tower yang membantu untuk pendinginan air yang membantu pendinginan di kondensor.

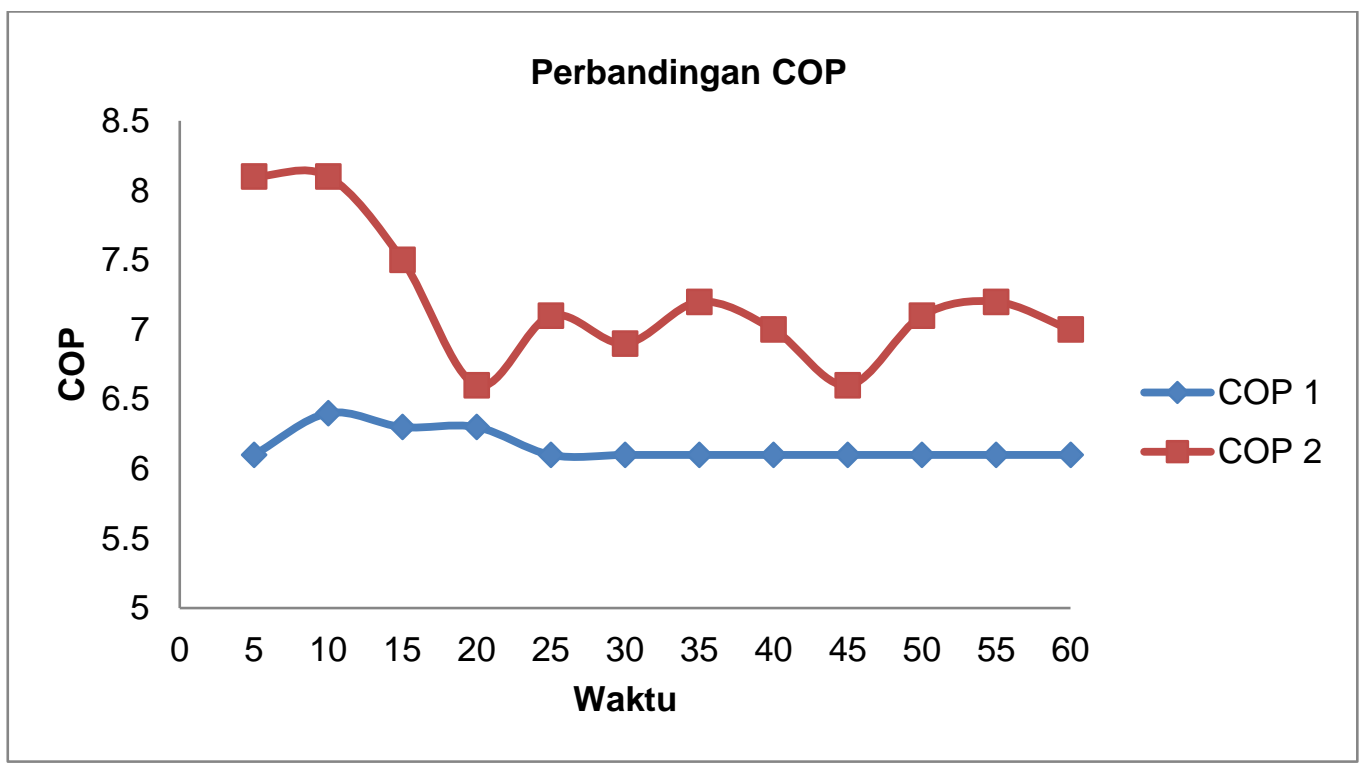

Gambar 8. Grafik Perbandingan Performansi Sistem (COP)

\section{KESIMPULAN}

Kesimpulan dari penelitian ini dengan penambahan komponen heat recovery dapat meningkatkan nilai $\mathrm{COP}$ sistem $A C$ chiller sebesar $14,46 \%$, hal ini disebabkan air yang mengalir melalui heat recovery membantu proses penyerapan kalor pada refrigerant yang baru keluar dari kompresor sehingga refrigerant yang keluar dari heat recovery akan mengalami penurunan temperatur sebelum memasuki kondensor. Pada refrigerant yang keluar dari kondesor juga mengalami penurunan tempertaur dikarenakan adanya media air yang membantu proses penyerapan kalor kembali sehingga pada sistem $A C$ chiller dengan penambahan heat recovery akan mengalami dua kali proses penyerapan 
kalor pada media air yang dapat menurunkan temperatur refrigerant lebih cepat

\section{DAFTAR PUSTAKA}

[1] Abdul Manan. 2014. Mechanical Engineering, Surabaya

[2] ASHRAE HANDBOOK. 2005. Fundamentals, American Society of Heating, Refrigeration and Air Conditioning Engineers. SI Edition.

[3] D.A. Reay, E \& F.N Span. 2008. Heat Recovery, London

[4] Herbert W Staford III. 2011. HVAC Water Chiller and Cooling Tower, New York: Marcel Dekker INC.

[5] Nursuhud. 2006. Jenis-jenis Alat Ukur. Andi, Yogyakarta.

[6] Rasta I Made. 2009. Pemanfaatan Energi Panas Terbuang pada Kondensor AC Sentral Jenis Water Chiller untuk Pemanas Air Hemat Energi, Jurnal IImiah Teknik Mesin Cakram Vol.3.

[7] Wilbert F. Stoecker and Jerold W. Jones. 1982. Refrigerasi dan Pengkondisian Udara. Jakarta. Erlangga. 